\title{
THE 1997 NOVAG AWARD
}

\author{
The Board of ICCA
}

In the past, the ICCA has awarded a prize to the author(s) for the publicatıon, which in the opinion of the judges, makes the biggest contribution to computer chess

For the first six years this award was known as the MEPHISTO AWARD in recognition of the German chesscomputer manufacturer, who generously provided the prizes As announced in Vol 18, No 2, this annual prize could be contınued by generosity of the Hong Kong chess-computer manufacturer NovAG, starting with the period April 1993 to March 1994 The winner of the first NOVAG AWARD was Rainer Feldmann for his Ph D thesis Game Tree Search with Massively Parallel Systems, followed by Aske Plaat, Jonathan Schaeffer, Wim Pijls and Arie de Bruin with their article A New Paradigm for Minımax Search in 1995 The 1996 Novag Award winner was Bob Hyatt for his July 1995 releases of the source code for the CRAFTY chess program

The period covered by the fourth NovaG AwarD is April 1996 to March 1997, both limits included The winner of the fourth NOVAG AWARD will be announced in Vol 20, No 4

\section{CALENDAR OF COMPUTER-GAMES EVENTS 1997}

\section{April 6-10, 1997}

Internatıonal Colloquium Board Games in Academia II, to be held in Leiden, The Netherlands

Detals from Alex de Voogt, Da Costalaan 1, 3743 HT Baarn, The Netherlands, Telephone +31 355430697 See also announcement at pp 58-59

\section{April 16-23, 1997}

The $12^{\text {th }}$ AEGON Man-Machine Tournament, to be held in The Hague, The Netherlands Detalls from Cock de Gorter, Valkenboskade 607, 2563 JE The Hague, The Netherlands, Telephone +31 7034643729 See also announcement at pp 57-58

\section{May 3-10, 1997}

The IBM Chess Challenge Rematch DeEP BLUE - Kasparov, to be held in New York, USA, at the Millenium on Broadway See also announcement in ICCA Journal, Vol 19, No 4, p 277

\section{July 27-28, 1997}

The AAAI-97 Workshop, to be held in Providence, Rhode Island, USA Detalls from Robert Morris, Computer Science Progiam, Florida Institute of Technology, $150 \mathrm{~W}$ University Blvd, Melbourne, FL 32901, Telephone (407) 768-8000, ext 7290, Fax (407) 984-8461 Emall morris@csfit edu See also announcement at pp 53-54

\section{August 18-24, 1997}

The First Mind Sports Olympiad to be held in the Royal Festival Hall in London Detarls from David Levy, 89, Constantıne Road, London NW3 2LP, England Emall DavidL@intrsrch demon co uk See also announcement on pp 56-57

\section{August 24-25, 1997}

The IJCAI-97 Workshop, to be held in Nagoya, Japan Detals from Hiroyukı IIda, Department of Computer Scıence, Shızuoka Unıversity, 3-5-1 Johoku, Hamamatsu, Shızuoka, 432 Japan Telephone +81 534781 456, Fax +81 534754595 Emall 11da@cs inf shızuoka ac jp See also announcement on pp 54-55

\section{Fall 1997}

The ICCA is negotiatıng to hold the $15^{\text {th }}$ World Microcomputer Chess Championship in Parıs, France The data will probably be withın the tıme fiame October 24 - November 4, 1997 